\title{
Biosimilar Drugs Market Future Trends in United States
}

Barkha $\mathbf{G}^{1^{*}}$ and Praneeth $\mathrm{K}^{2}$

${ }^{1}$ Amity Institute of Biotechnology, Amity University, Noida, India

${ }^{2}$ Department of Pharmaceutical sciences, The University of Greenwich, London, UK

*Corresponding author: Barkha G, Amity Institute of Biotechnology, Amity University, Noida, India, Tel: 011-22932958; E-mail: barkhagupta000@gmail.com

Received date: March 09, 2017; Accepted date: March 14, 2017; Published date: April 14, 2017

Copyright: (C) 2017 Barkha G, et al. This is an open-access article distributed under the terms of the Creative Commons Attribution License, which permits unrestricted use, distribution, and reproduction in any medium, provided the original author and source are credited.

\section{Commentary}

USA is a largest market of biologics globally. Biosimilar market expected to represent CAGR of $62.2 \%$ as the chances of growth of biosimilar market from $\$ 1.7$ billion in 2014 to $\$ 30$ billion by 2020 . Currently USA is a very small market for biosimilar but it can grow as the largest contributor for biosimilars as major share (upto $10 \%$ ) of the global revenue is generated from USA. Biosimilar therapy is a very effective way of treating disease conditions like cancer, rheumatoid, Crohn's disease, ankylosing spondylitis, psoriatic arthritis, plaque psoriasis and many autoimmune disorders [1].

Pressure is generated on biosimilar market due to average pricing discount from past few tenders. This condition can be regulated by many government supports. Trend of biosimilar in the market of America has been developed by the approval and regulatory process [2-4]. In 2010, patient care act was passed by Obama which give licensure pathway for interchangeable products, which provided under the part of Biologics Price Competition and Innovation Act for the product demonstrating as biosimilar, manufacturers need to submit Biologics License Application (BLA) [2].

Target reference products for the USA market are Monoclonal Antibodies (MAbs), recombinant protein and some high-purity protein products, out of which recombinant therapeutic with large market (sales) even with small profitable amount. USA has approximate patent expiration date of 15 years for innovator drug after which it becomes susceptible to biosimilar competition by 2020. About 119 recombinant proteins marketed out of which 30 are susceptible to biosimilar. There are $\geq 10$ biosimilars USA Company reported in development. Overall $15 \%$ increase in business is reported by Contract Manufacturing Organizations (CMOs) from biosimilars launch in USA market.

Major products of USA biosimilar markets are Remicade, Enbrel, Rituximab, Adalimumab, Infliximab, Etanercept, Darbepoetin alpha. Key players for USA Biosimilar product markets are Sandoz, Amgen, Teva Pharmaceutical Industries, Hospira, STADA Arzneimittel, Mylan $[4,5]$.

There are $10-260$ biosimilars under pipeline as per CMO, by the report of center of drug evaluation and research 4-6 licensed biological products are interchangeable (11/23/2016).

Any size and type of company can enter in biosimilar market but competition will be high for the drivers with the greatest number of innovator drug.

As per the report of IMS Institute for Health Informatics (2015), 41 biosimilars are under development out of which 23 biosimilars are ready to be released into market [6]. A large number of biosimilars are in pipeline and are predicted to be marketed soon [7]. M923, a biosimilar HUMIRA (adalimumab) under the phase-III trial and will be marketed soon by Momenta. Sandoz being more experienced in the industry was the first to get approval of a biosimilar in the US as per the new FDA biosimilars pathway established under the BPCIA [8]. Many crucial biosimilar are under pipeline by Teva Inc. including TVB018 CT-P10 (Rituxan), CT-P6 (Herceptin) and have received approval for tbo-filgrastim (XM02 filgrastim) by USFDA [9]. Herceptin is targeted by Mylan with the submission of FDA biosimilar approval. Another market driver Pfizer has introduced Remicade biosimilar at $15 \%$ discount in USA [10-12].

Biosimilar has almost $8 \%$ of patients throughout the world due to high price. However, manufacturing cost is high compared to biologics and establishment of biosimilar is a real time challenge for pharmaceutical companies at affording price for the class of patients and treatment. Competition for the biosimilar development is accelerating with high speed due to consistent demand worldwide $[13,14]$. They are highly complex biomolecules small change in production can lead to major implication in safety. USA has greatest opportunities for biosimilars as biologics has higher price. Biosimilars are high potential for the pharmaceutical market due to physician acceptance owing to low risk of challenging immunity and diligence [15].

\section{References}

1. Emerton DA (2013) Profitability in the Biosimilars Market. BioProcess International 11: 1-23.

2. Food and Drug Administration (FDA) (2016) Information on Biosimilars. Silver Spring, USA.

3. Food and Drug Administration (FDA) (2016) Therapeutic Biologic Applications (BLA), Biosimilars. Silver Spring, USA.

4. Biosimilar Development (2016) Pharma Leader Series 25 Top Biosimilar Drug Manufacturers 2016-2026. PR newswire, London.

5. https://www.pfizermedicalinformation.com/en-us

6. Lifetime Trends in Biopharmaceutical Innovation (2016) IMS Institute for Health Informatics. USA.

7. Oncobiologics (2017) Understanding Biosimilars Development, Product pipeline. New Jersey, USA.

8. https://www.sandoz.com/our-work/biopharmaceuticals

9. Sandoz Biosimilar Pipeline (2016) TEVA Pharmaceutical Industries Ltd., Israel.

10. Mylan (2016) Mylan and Biocon Announce U.S. FDA Submission for Proposed Biosimilar Trastuzumab. Silver Spring, USA.

11. FDA News room (2015) FDA approves first biosimilar product Zarxio. Silver Spring, USA.

12. FDA News room (2016) FDA approves Inflectra, a biosimilar to Remicade. Silver Spring, USA.

13. http://www.prnewswire.com/news-releases/pharma-leader-series-top-30pharmaceutical-contract-manufacturing-organisations-cmos---marketindustry-trends-technologies-and-prospects-2015-2025-531033371.html 
Citation: Barkha G, Praneeth K (2017) Biosimilar Drugs Market Future Trends in United States. Pharm Anal Acta 8: 543. doi: 10.4172/2153-2435.1000543

Page 2 of 2

14. Vulto A, Crow AS (2012) Risk management of biosimilars in oncology: 15. FDA News room (2016) FDA approves Erelzi, a biosimilar to Enbrel. each medicine is a work in progress. Targeted Oncology 7: 43-49. Silver Spring, USA. 